\title{
High variability of primary production in oligotrophic waters of the Atlantic Ocean: uncoupling from phytoplankton biomass and size structure
}

\author{
Emilio Marañón ${ }^{1, *}$, Michael J. Behrenfeld ${ }^{2}$, Natalia González ${ }^{3}$, Beatriz Mouriño ${ }^{1}$, \\ Mikhail V. Zubkov ${ }^{4}$ \\ ${ }^{1}$ Departamento de Ecología y Biología Animal, Facultad de Ciencias, Universidad de Vigo, 36200 Vigo, Spain \\ ${ }^{2}$ National Aeronautics and Space Administration, Goddard Space Flight Center, Code 971, Building 33, \\ Greenbelt, Maryland 20771, USA \\ ${ }^{3}$ Departamento de Matemáticas, Física Aplicada y Ciencias de la Naturaleza, Universidad Rey Juan Carlos, 28933 Móstoles, \\ Madrid, Spain \\ ${ }^{4}$ George Deacon Division for Ocean Processes, Southampton Oceanography Centre, University of Southampton \\ Southampton SO14 3ZH, United Kingdom
}

\begin{abstract}
The oligotrophic waters of the Subtropical Gyres cover $>60 \%$ of the total ocean surface and contribute $>30 \%$ of the global marine carbon fixation. Despite apparently uniform growth conditions over broad areas, primary production in these regions exhibits a remarkable degree of variability. In this study of 34 stations in the North and South Atlantic Subtropical Gyres, we found a 20 -fold variation (from 18 to $362 \mathrm{mg} \mathrm{C} \mathrm{m}^{-2} \mathrm{~d}^{-1}$ ) in water-column-integrated primary production rate $($ PP), while chlorophyll biomass only varied by a factor of 3 . The changes in productivity were not associated with variations in incident surface irradiance, chlorophyll concentration, phytoplankton C biomass or phytoplankton size structure. The rate of nutrient supply to the euphotic layer, as estimated from variations in the depth of nitracline, appeared as the most relevant environmental factor in explaining the observed variability in SPP. We found significant changes in the composition of the picophytoplankton community across the range of measured productivities. The relative biomass contribution of Synechococcus spp. and the picoeukaryotes tended to increase with increasing $\int \mathrm{PP}$, whereas the opposite was true for Prochlorococcus spp. Across the wide range of measured primary productivity rates, the persistent dominance of picophytoplankton indicates that the microbial loop and the microbial food web continued to be the most important trophic pathways. Our observations of the oligotrophic ocean reflect a dynamic ecosystem where the microbial community responds to environmental forcing with significant changes in biological rates rather than trophic organization.
\end{abstract}

KEY WORDS: Primary production · Chlorophyll · Picoplankton · Size structure · Subtropical Gyres · Atlantic Ocean

\section{INTRODUCTION}

In the Subtropical Gyres of the open ocean, the strong vertical stratification of the water column limits the supply of nutrients from below the thermocline to the euphotic layer. As a result, carbon fixation by primary producers in these oligotrophic regions is low (typically below 0.3 to $0.4 \mathrm{~g} \mathrm{C} \mathrm{m}^{-2} \mathrm{~d}^{-1}$ : see Longhurst et al. 1995). Despite their low areal productivities, these regions, which cover $>60 \%$ of the total ocean surface area, may account for $>30 \%$ of the total marine primary production (Longhurst et al. 1995). Time-series studies have shown that photosynthetic $C$ fixation in the Subtropical Gyres displays a significant degree of variability, both at seasonal and interannual time scales (see reviews in Karl et al. 2001, Steinberg et al. 
2001). Given the large impact of the Subtropical Gyres on global biogeochemical budgets, it seems necessary to quantify how variable productivity is within these regions (with both spatial heterogeneity and temporal considered together), identify the causative mechanisms of this variability, and evaluate its implications for large-scale production estimates.

The Atlantic Meridional Transect (AMT) programme represents an effort to study the ecology and biogeochemistry of the upper ocean on very large spatial scales (Aiken \& Bale 2000). Previous studies within the AMT programme have reported the latitudinal patterns in picophytoplankton composition (Zubkov et al. 1998, 2000) as well as phytoplankton photophysiology (Marañón \& Holligan 1999), production (Marañón et al. 2000) and size structure (Marañón et al. 2001). A comparison of successive AMT cruises suggested that changes in primary production in oligotrophic waters are not associated with significant differences in phytoplankton chlorophyll concentration (Marañón et al. 2000). None of these studies, however, specifically addressed the variability of phytoplankton within the Subtropical Gyres.

From an ecological perspective, variability of primary production in the face of nearly constant phytoplankton biomass poses a number of relevant questions. It has long been assumed that changes in primary production are mostly mediated by an enhancement in the relative contribution of larger cells to total biomass and production. However, the temporal variability in primary production at particular ultraoligotrophic sites of the Atlantic Ocean do not seem to be associated with major changes in the size structure of the phytoplankton assemblages (Marañón et al. 2001). It is nevertheless possible that variations in primary productivity are related to subtle compositional changes within the picophytoplankton (e.g. Liu et al. 1999) that do not necessarily imply changes in total microbial biomass or size structure. For instance, the relative contribution of Synechococcus spp., Prochlorococcus spp. and picoeukaryotes to total picophytoplankton abundance has been shown to change markedly during the year in response to hydrodynamical forcing (e.g. Campbell et al. 1997, Gin et al. 1999). However, a specific analysis of the relationship between primary production and picophytoplankton biomass and composition in the Subtropical Gyres of the Atlantic Ocean has not yet been conducted.

The present contribution addresses the variability of phytoplankton biomass and size structure, picophytoplankton composition and primary production in the North and South Atlantic Subtropical Gyres. Specifically, we describe the ecological characteristics of microbial plankton in the Eastern North Atlantic Subtropical Gyre and the South Atlantic Tropical Gyre bio- geographic provinces as defined by Longhurst (1998). Our aims were to (1) quantify the combined spatial and temporal variability of $\mathrm{C}$ fixation rates, (2) assess the relative importance of different environmental factors in explaining this variability, and (3) investigate the relationship between primary production and community structure in the oligotrophic Atlantic Ocean.

\section{MATERIALS AND METHODS}

Sampling was conducted on board the RRS 'James Clark Ross' during May and October 1996, and May and October 1997 as part of the Atlantic Meridional Transect (AMT) programme. At each station, vertical profiles of temperature and salinity were obtained with a Neil Brown Mark IIIB CTD. The vertical attenuation of photosynthetically active radiation (PAR) was calculated with a SeaWiFS Optical Profiling System equipped with a set of 7 -channel light sensors. Incident $\operatorname{PAR}\left(E_{0}\right)$ was continuously measured by a delta-T Instruments PAR sensor connected to the ship's ocean logger system.

Water samples from 7 to 10 discrete depths were collected at 10:00 to 11:00 h local time using metal-free, lever-action Teflon Go-Flo bottles, which did not have any internal rubber pieces and were provided with silicone O-rings and seals. The bottles had been modified for trace-metal sampling and were mounted on an epoxy paint-coated rosette frame (Bowie et al. 2002). Typically, we collected 3 to 4 samples from the upper mixed layer, 2 to 3 samples from the deep chlorophyll maximum (DCM) and 1 to 2 samples from below the DCM. Micromolar concentrations of nitrate and phosphate were determined on fresh samples using a Technicon AAII autoanalyser and standard techniques. The detection level was $0.05 \mu \mathrm{M}$ for nitrate and $0.01 \mu \mathrm{M}$ for phosphate. For each station, the depth of the nitracline was taken to be the first depth where nitrate was detected $(>0.05 \mu \mathrm{M})$. Size-fractionated chlorophyll a concentration was determined fluorometrically after sequential filtration of $250 \mathrm{ml}$ samples through 20, 2 and $0.2 \mu \mathrm{m}$ polycarbonate filters. Pigment extraction was carried out by keeping the filters in $90 \%$ acetone at $-20^{\circ} \mathrm{C}$ overnight. Samples were then analysed using a 10 AU Turner Designs fluorometer, following the non-acidification method. From the surface and the depth of the deep chlorophyll maximum, samples were collected for the microscopic identification and counting of nano- and microphytoplankton following the procedures described in Marañón et al. (2000).

The vertical distribution of the rate of $\mathrm{C}$ fixation by each size class was determined in on-deck incubations with the radioisotope ${ }^{14} \mathrm{C}$, as described in Marañón et al. (2001). Particular care was taken to avoid any trace- 
metal contamination of the samples and any light shock to the phytoplankton. We used polycarbonate incubation bottles, which had been cleaned by soaking them in $1 \mathrm{~N} \mathrm{HCl}$ overnight and then rinsing them 3 times with deionized water. Seawater samples were transferred from the Niskin bottles to the incubation bottles under dim light conditions using acid-washed silicone tubes. For each sampling depth, we filled 3 light bottles and 1 dark bottle, inoculated them with 10 to $15 \mu \mathrm{Ci}$ of $\mathrm{NaH}^{14} \mathrm{CO}_{3}$, and incubated them for 6 to $7 \mathrm{~h}$ until sunset. Samples were placed in an on-deck incubator which was refrigerated by a system of running seawater pumped from the sea surface. The incubator consisted of a set of cylinders, each provided with a combination of neutral density and blue plastic filters that simulated the irradiance levels experienced by phytoplankton at their original sampling depth. This incubation equipment is identical to that used by Joint et al. (1993) in their productivity experiments during the North Atlantic Bloom Experiment (NABE). These authors did not find any significant differences between the productivity estimates obtained from in situ incubations and those obtained from on-deck incubations.

At the end of our experiments, samples were sequentially filtered through 20,2 and $0.2 \mu \mathrm{m}$ polycarbonate filters under low-vacuum pressure. After decontaminating the filters with $\mathrm{HCl}$ fumes, the radioactivity of each sample was determined with a Beckman LS6000 SC scintillation counter. Dark-bottle DPM values were subtracted from the counts measured in the light samples. The average coefficient of variation in our measurements of total primary production was $16 \%$. Daily production rates were calculated as in Marañón et al. (2000), by taking into account the integrated incident irradiance (PAR) during both the incubation and the daylight time periods and by assuming that dark respiratory losses were $20 \%$ of the total C fixed during the hours of light (Geider 1992). For each productivity profile (no smoothing was applied), we extracted the value of $P^{B}{ }_{\text {opt }}$ which is the highest, chlorophyll-normalised $\mathrm{C}$ fixation rate in the water column.

We assessed if the fact that our incubations did not cover the whole photoperiod was causing any bias in our productivity measurements. We did not find any significant differences between the average incident irradiance registered during the incubation period and the average irradiance measured throughout the day. In addition, short $(7 \mathrm{~h})$ and long $(24 \mathrm{~h})$ incubations were conducted in parallel at 4 stations during the AMT-6 cruise (April 1998) with the aim of evaluating the effect of incubation time on the results of the experiments. The correlation between the estimates of primary productivity obtained from both types of experiments was highly significant $\left(\mathrm{r}^{2}=0.87, \mathrm{n}=16\right.$, $\mathrm{p}<0.001$ ), and the slope of the linear regression equation (0.86) was not significantly different from 1 . These results make us confident that the use of 6 to $7 \mathrm{~h}$ long incubations was not causing any bias in our measurements of primary production.

In October 1996 and May 1997, the vertical distribution of the abundance of Synechococcus spp., Prochlorococcus spp. and photosynthetic picoeukaryotes was determined by flow cytometry as described in Zubkov et al. (1998). Samples were fixed with 0.1 to $0.3 \%$ glutaraldehyde, frozen and kept in liquid nitrogen or at $-30^{\circ} \mathrm{C}$ until analysis 1 to 2 mo later. Samples were analysed in an FACSort flow cytometer equipped with a $15 \mathrm{~mW}$ laser exciting at $488 \mathrm{~nm}$. Synechococcus spp., Prochlorococcus spp. and picoeukaryotic cells were identified and counted using their group-specific sidescatter and autofluorescence properties. Fluorescent latex beads of $1 \mu \mathrm{m}$ diameter were used to calibrate the sidescatter signal into units of size. In addition, several experiments were conducted in which samples were filtrated through filters of varying pore sizes. The intact sample and the filtrates were counted by flow cytometry, and the regression between relative cell concentration and pore size was used to determine the average cell size of each taxonomic group. According to size fractionation, the average cell size of picoeukaryotes in the oligotrophic ocean was $1.4 \pm$ $0.13 \mu \mathrm{m}$. This suggests that although we cannot rule out the possibility that some larger $(>2 \mu \mathrm{m})$ cells were also counted, their relative influence in our estimates of picoeukaryote biomass was likely to be small. Cell numbers were converted into carbon biomass estimates as described in Zubkov et al. (1998). Following Kirchman (2002), growth rates of picophytoplankton for the euphotic layer were calculated directly by dividing the integrated, daily primary production rate in the $<2 \mu \mathrm{m}$ size fraction by the integrated picophytoplankton C biomass.

For the present analysis, we selected those stations sampled during the AMT transects located within the boundaries of the Eastern North Atlantic Subtropical Gyre (NAST-E, 9 stations) and the South Atlantic Tropical Gyre (SATL, 25 stations) biogeographic provinces, as defined by Longhurst (1998) (Fig. 1). These are biogeographic provinces where vertical mixing is weak and therefore oligotrophic conditions prevail during most of the year (Longhurst 1998). Features common to all 34 stations studied were: (1) a well-developed pycnocline at $>50 \mathrm{~m}$ depth; (2) a marked deep chlorophyll maximum at $>60 \mathrm{~m}_{i}$ (3) a surface nitrate concentration below $0.05 \mu \mathrm{M}_{i}(4)$ a nitracline at $>70 \mathrm{~m}$ depth; (5) a euphotic zone-integrated chlorophyll a concentration and primary production rate below ca. $35 \mathrm{mg} \mathrm{m}^{-2}$ and ca. $350 \mathrm{mg} \mathrm{C} \mathrm{m}^{-2} \mathrm{~d}^{-1}$, respectively. We excluded 


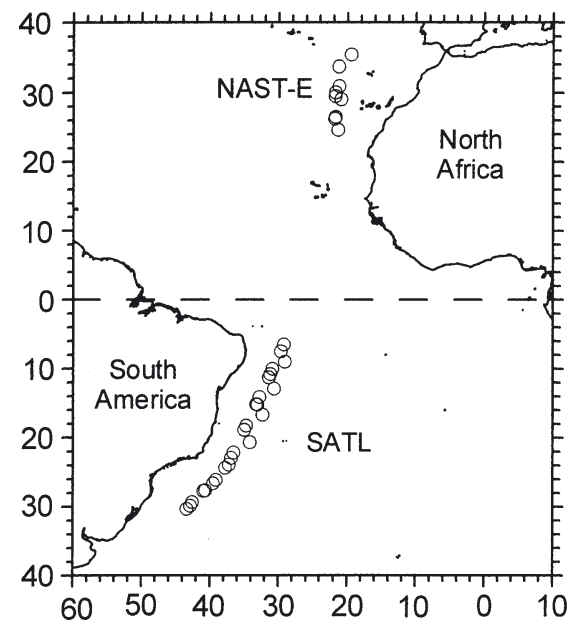

Fig. 1. Location of the 34 oligotrophic stations sampled during this study: 9 stations in the Eastern North Atlantic Subtropical Gyre (NAST-E) and 25 stations in the South Atlantic Tropical Gyre (SATL)

from our analysis the observations conducted within the North Atlantic Tropical Gyre (NATR) and the Western Tropical Atlantic (WTRA) provinces. Along the AMT cruise track, NATR and WTRA stations are heavily influenced by the coastal upwelling off Mauritania and the Equatorial uwelling, respectively, and have a mesotrophic nature.

\section{RESULTS}

SATL had warmer surface waters and deeper nitraclines than NAST-E (Table 1, Fig. 2), indicating stronger stratification in the southern province. In both provinces, nitrate was undetectable $(<0.05 \mu \mathrm{M})$ in the upper 70 to $80 \mathrm{~m}$ of the water column, whereas low concentrations of phosphate (ca. 0.01 to $0.02 \mu \mathrm{M})$ were measured throughout the upper mixed layer. Silicate concentration in the upper mixed layer was typically above $0.4 \mu \mathrm{M}$ in both provinces (data not shown). Average iron concentrations in the upper mixed layer were $>0.6 \mathrm{nM}$, concentrations that are unlikely to result in iron-limitation of phytoplankton production (Bowie et al. 2002). The deep chorophyll (chl) maximum was deeper in SATL, which showed a significantly higher integrated chl a concentration. In contrast, integrated primary production at SATL $(171 \pm 80 \mathrm{mg} \mathrm{C}$ $\left.\mathrm{m}^{-2} \mathrm{~d}^{-1}\right)$ was lower than that at NAST-E $(264 \pm 69 \mathrm{mg} \mathrm{C}$ $\mathrm{m}^{-2} \mathrm{~d}^{-1}$ ), resulting in significantly lower values of the maximum, chl-normalised $\mathrm{C}$ fixation rate within the water column $\left(P^{B}\right.$ opt $)$. No significant differences in picophotoautotroph biomass or size-partitioning of $\mathrm{chl} a$ and primary production were observed between provinces. Picophytoplankton accounted for 77 to $80 \%$ of total chl $a$ and 55 to $57 \%$ of total $C$ fixation (Table 1). The integrated, C-specific growth rate of the picophotoautotrophs averaged $0.2 \mathrm{~d}^{-1}$ in both provinces. The upper mixed layer $\mathrm{C}$-specific growth rates were somewhat higher, and averaged $0.3 \mathrm{~d}^{-1}$ in both provinces.

Total integrated primary production ( $(\mathrm{PP})$ varied over a 20-fold range from 18 to $364 \mathrm{mgC} \mathrm{m}^{-2} \mathrm{~d}^{-1}$ (Fig. 3). In contrast, station-to-station changes in chl a concentration were highly stable, varying by only a factor of 3 from 13 to $35 \mathrm{mg} \mathrm{m}^{-2}$ (Fig. 3) There was no significant relationship between $\int \mathrm{PP}$ and surface or integrated chl a concentration (Fig. 3, Table 2). Daily average incident PAR $\left(E_{0}\right)$ exhibited greater variability than chl a but was also uncorrelated with changes in

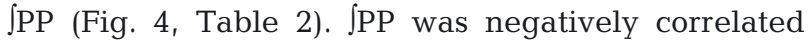
with both sea-surface temperature (SST) $(r=-0.60$, $p<0.001)$ and the depth of the nitracline $(r=-0.51$, $\mathrm{p}<0.01$ ), which can be used as a proxy for the rate of nutrient supply into the euphotic zone (e.g. Malone et al. 1993). Stations with low $C$ fixation rates had very warm $\left(>26^{\circ} \mathrm{C}\right)$ surface temperatures and very deep $(>100 \mathrm{~m})$ nitraclines, while the most productive stations tended to have colder surface waters and shallower nitraclines (Fig. 4). In addition, there was a significant, inverse correlation between $P^{B}{ }_{\text {opt }}$ and nitracline depth $(\mathrm{r}=-0.46, \mathrm{p}<0.05)$.

Table 1. Means $( \pm \mathrm{SD})$ of several physical, chemical and biological properties measured during our study in North Atlantic Subtropical Gyre (NAST-E) and South Atlantic Tropical Gyre (SATL) biogeographic provinces (DCM: deep chlorophyll maximum). Also shown is significance (p) of the observed differences (Student's $t$-test) at the 95\% confidence level: ${ }^{*} \mathrm{p}<0.05 ;{ }^{* *} \mathrm{p}<0.01$; ${ }^{* * *} \mathrm{p}<0.001$; ns: not significant

\begin{tabular}{|c|c|c|c|}
\hline Variable & NAST-E & SATL & $\mathrm{p}$ \\
\hline Surface temperature $\left({ }^{\circ} \mathrm{C}\right)$ & $22.3 \pm 2.2$ & $25.1 \pm 2.4$ & ** \\
\hline Nitracline depth $(\mathrm{m})$ & $93 \pm 15$ & $120 \pm 26$ & $* *$ \\
\hline Surface chl a $\left(\mathrm{mg} \mathrm{m}^{-3}\right)$ & $0.08 \pm 0.03$ & $0.12 \pm 0.06$ & ns \\
\hline DCM depth $(\mathrm{m})$ & $94 \pm 13$ & $106 \pm 27$ & ns \\
\hline Integrated chl a $\left(\mathrm{mg} \mathrm{m}^{-2}\right)$ & $20.4 \pm 4.8$ & $24.4 \pm 4.9$ & ${ }^{*}$ \\
\hline $\begin{array}{l}\text { Integrated primary production } \\
\left(\mathrm{mg} \mathrm{C} \mathrm{m}^{-2} \mathrm{~d}^{-1}\right)\end{array}$ & $264 \pm 69$ & $171 \pm 80$ & ${ }^{* *}$ \\
\hline$P_{\text {opt }}^{B}\left(\mathrm{mg} \mathrm{C} \mathrm{mg}^{-1} \mathrm{chl} a \mathrm{~h}^{-1}\right)$ & $4.6 \pm 2.3$ & $2.2 \pm 1.2$ & *** \\
\hline \% picoplankton chl a & $77 \pm 8$ & $80 \pm 6$ & ns \\
\hline \% picoplankton production & $55 \pm 19$ & $57 \pm 12$ & ns \\
\hline Picophytoplankton biomass $\left(\mathrm{g} \mathrm{C} \mathrm{m}^{-2}\right)$ & $0.60 \pm 0.14$ & $0.58 \pm 0.10$ & ns \\
\hline $\begin{array}{l}\text { Picophytoplankton integrated } \\
\text { growth rate }\left(\mathrm{d}^{-1}\right)\end{array}$ & $0.20 \pm 0.11$ & $0.23 \pm 0.08$ & ns \\
\hline
\end{tabular}




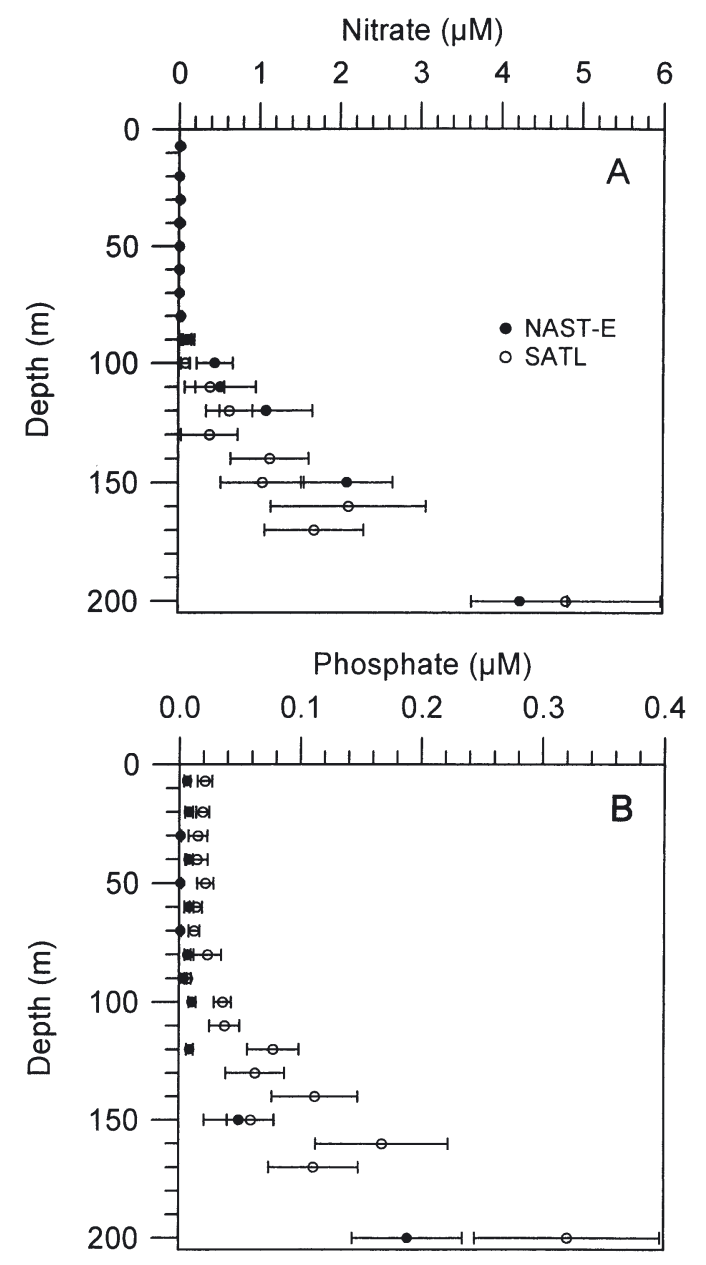

Fig. 2. Average $( \pm 1 \mathrm{SE})$ vertical profiles of $(\mathrm{A})$ nitrate and (B) phosphate concentration $(\mu \mathrm{M})$ in North Atlantic Subtropical Gyre (NAST-E) and South Atlantic Tropical Gyre (SATL)

The use of simulated 'in situ' (SIS) incubations could potentially give rise to station-to-station variability in our estimates of $\int \mathrm{PP}$. We tested this possibility by comparing the $P^{B}{ }_{\text {opt }}$ values obtained from the productivity profiles with the $P^{B}{ }_{\text {max }}$ (light-saturated photosynthesis per unit chl a) values obtained for surface phytoplankton from the $P-E$ experiments conducted during May and October 1996 in oligotrophic waters (see Marañón \& Holligan 1999 for details). The correlation between $P^{B}{ }_{\text {opt }}$ and surface $P^{B}{ }_{\max }$ was highly significant $(\mathrm{r}=0.91$, $\mathrm{n}=14, \mathrm{p}<0.01)$. Given that the measurements of $P^{B}{ }_{\text {opt }}$ and $P^{B}{ }_{\text {max }}$ are largely independent (i.e. on-deck incubations during 6 to $8 \mathrm{~h}$ versus $2 \mathrm{~h}$ long $P$-E experiments in a laboratory incubator), the fact that both variables covaried supports our estimates of $\int \mathrm{PP}$ and excludes the possibility that the observed variability in $\int \mathrm{PP}$ was due to methodological artefacts derived from the use of SIS incubations.
Table 2. Pearson's correlation coefficient (r) between total integrated primary production $\left(\mathrm{mg} \mathrm{C} \mathrm{m}^{-2} \mathrm{~d}^{-1}\right)$ and selected physical, chemical and biological variables. Significance evaluated at $95 \%$ confidence level ( $\mathrm{p} \leq 0.05)$. $\mathrm{n}$ : number of data points in each analysis. ${ }^{*} \mathrm{p}<0.05$; ${ }^{* *} \mathrm{p}<0.01 ;{ }^{* * *} \mathrm{p}<0.001 ;$ ns: not significant

\begin{tabular}{|lrcc|}
\hline Variable & $\mathrm{r}$ & $\mathrm{p}$ & $\mathrm{n}$ \\
\hline Sea-surface temperature $\left({ }^{\circ} \mathrm{C}\right)$ & -0.60 & ${ }^{* * *}$ & 34 \\
Incident average PAR $\left(\mu \mathrm{mol} \mathrm{m}^{-2} \mathrm{~s}^{-1}\right)$ & 0.02 & $\mathrm{~ns}$ & 34 \\
Nitracline depth $(\mathrm{m})$ & -0.51 & ${ }^{* *}$ & 33 \\
Surface chl $\mathrm{a}\left(\mathrm{mg} \mathrm{m}^{-3}\right)$ & -0.07 & $\mathrm{~ns}$ & 34 \\
Integrated chl $\mathrm{a}\left(\mathrm{mg} \mathrm{m}^{-2}\right)$ & -0.33 & $\mathrm{~ns}$ & 34 \\
$\%$ integrated chl $\mathrm{a}<2 \mathrm{\mu m}$ & -0.27 & $\mathrm{~ns}$ & 34 \\
$\%$ integrated productivity $<2 \mu \mathrm{m}$ & 0.06 & $\mathrm{~ns}$ & 34 \\
Synechococcus spp. C biomass $\left(\mathrm{gC} \mathrm{m}^{-2}\right)$ & 0.22 & $\mathrm{~ns}$ & 18 \\
Prochlorococcus spp. C biomass $\left(\mathrm{gC} \mathrm{m}^{-2}\right)$ & -0.58 & $*$ & 18 \\
Picoeukaryotes C biomass $\left(\mathrm{gC} \mathrm{m}^{-2}\right)$ & 0.18 & $\mathrm{~ns}$ & 18 \\
Integrated picophytoplankton & -0.25 & $\mathrm{~ns}$ & 18 \\
C biomass (mg C m $\left.{ }^{-2}\right)$ & & & \\
\hline
\end{tabular}

A photoacclimation and nutrient-based model of light-saturated photosynthesis (the 'PhotoAcc model') has recently been proposed for calculating oceanic primary production (Behrenfeld et al. 2002). The PhotoAcc model estimates $P^{B}{ }_{\text {opt }}$ or $P^{B}{ }_{\text {max }}$ by describing the relative changes in the Calvin cycle capacity and chlorophyll for 3 broad environmental conditions: (1) nutrient-sufficient growth within the mixed layer, (2) nutrient-sufficient growth below the mixed layer, and (3) nutrient-depleted growth above the nitracline. Our observations in the oligotrophic gyres, which showed high variability in $\int \mathrm{PP}$ with very small changes in chl concentration, constituted a good testing ground for the model's performance. The model was parameterised using $P-E$ observations made during April and September 1996 along the whole AMT cruise track, and applied to estimate $P^{B}{ }_{\text {opt }}$ and $P^{B}{ }_{\text {max }}$ at oligotrophic stations during April and September 1997. We found a

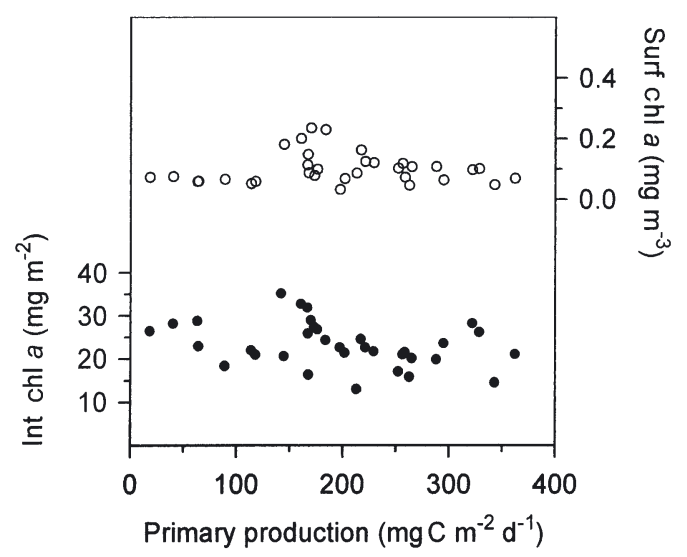

Fig. 3. Relationship between total integrated primary production and both surface (Surf) and integrated (Int) chl a concentration 


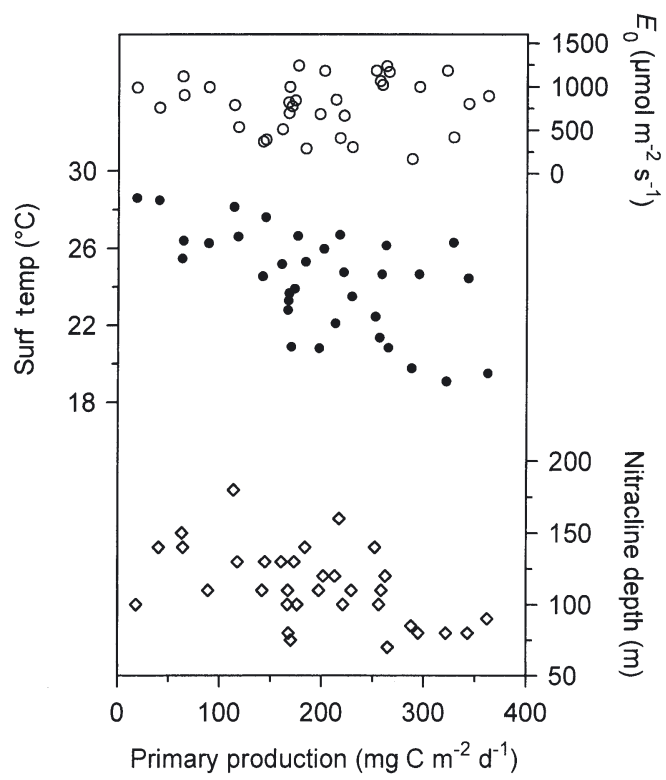

Fig. 4. Relationship between total integrated primary production and incident photosynthetically active radiation, PAR

$\left(E_{\mathrm{o}}\right)$, sea-surface temperature and nitracline depth

good agreement between observed (obs) and modelled (mod) $P_{\text {opt }}^{B}$ and $P_{\text {max }}^{B}$ (mod $=0.84 \times$ obs $+0.84, \mathrm{r}^{2}=0.76$, $\mathrm{n}=38, \mathrm{p}<0.01)$, indicating that the PhotoAcc model captures most of the variability in $P^{B}{ }_{\text {opt }}$ and $P^{B}{ }_{\text {max }}$ that takes place in the oligotrophic Atlantic gyres.

Variability in $\int \mathrm{PP}$ was not associated with any significant changes in the size structure of the phytoplankton assemblages (Fig. 5). The distribution of chl $a$ in different size classes was remarkably constant across the entire range of productivity rates and did not show any significant correlation with $\int \mathrm{PP}$ (Table 2 ). The average contribution of picoplankton to total chl a was $79 \%$. A higher degree of variability was observed in the partitioning of production between small $(<2 \mu \mathrm{m})$ and large $(>2 \mu \mathrm{m})$ phytoplankton: the contribution of the picophotoautotrophs to total productivity ranged between 30 and $80 \%$ (Fig. 5), but was also uncorrelated with the changes in $\mathrm{C}$ fixation rates (Table 2). The fact that the contribution of picophytoplankton to total primary production was significantly lower than their share of total chl a has been discussed elsewhere (Fernández et al. 2003).

We assessed if there were any relationship between primary production by larger phytoplankton $(>2 \mu \mathrm{m})$ and phytoplankton abundance in this size fraction, expressed either as chl a concentration or actual C biomass. We did not find any significant correlation between integrated production and chl a concentration in the $>2 \mu \mathrm{m}$ size fraction (Fig. 6A). Similarly, there was no relation between primary production by phytoplankton $>2 \mu \mathrm{m}$ in surface samples and the total esti- mated C biomass of surface nano- and microphytoplankton (Fig. 6B). A similar comparison was conducted between the $\mathrm{C}$ biomass and the productivity of the picophytoplankton. In this case, it was possible to calculate integrated values, given that picophytoplankton biomass estimates were available for the whole euphotic layer. Fig. 7A shows that there was no relationship between integrated picophytoplankton $\mathrm{C}$ and integrated picophytoplankton productivity $(\mathrm{r}=$ $-0.006, \mathrm{p}>0.05, \mathrm{n}=18$ ).

Size-fractionation experiments are only a crude approach to the study of the structure of the planktonic assemblages, since they may not detect compositional changes within one particular size class. In our study, the relative composition of the photoautotrophic picoplankton varied across the range of measured productivities (Fig. 7B). While the biomass of Synechococcus spp. and the picoeukaryotes did not show any significant change with $\int \mathrm{PP}$, Prochlorococcus spp. biomass decreased significantly with increasing $\int \mathrm{PP}(\mathrm{r}=-0.58$, $\mathrm{p}<0.05$, Table 2). In the less productive stations, the picophytoplankton community was heavily dominated by Prochlorococcus spp. As productivity increased, the abundance of Prochlorococcus spp. decreased significantly, and as a result the relative contribution of Synechococcus spp. and the picoeukaryotes to total biomass increased markedly.

\section{DISCUSSION}

\section{Phytoplankton biomass and productivity}

The rate of euphotic layer-integrated primary production (JPP) varied by a factor of 20 during our study.

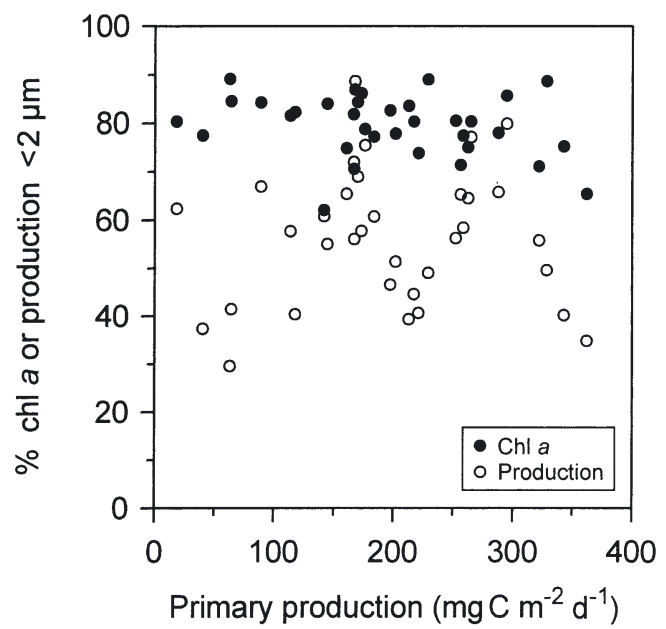

Fig. 5. Relationship between total integrated primary production and the percentage of the total integrated chl $a$ and production in $<2 \mu \mathrm{m}$ size fraction 


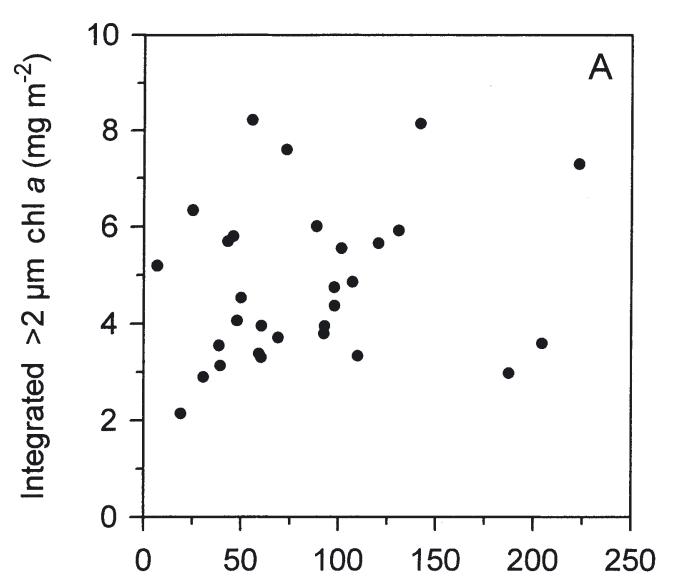

Integrated $>2 \mu \mathrm{m}$ production $\left(\mathrm{mg} \mathrm{C} \mathrm{m}^{-2} \mathrm{~d}^{-1}\right.$ )

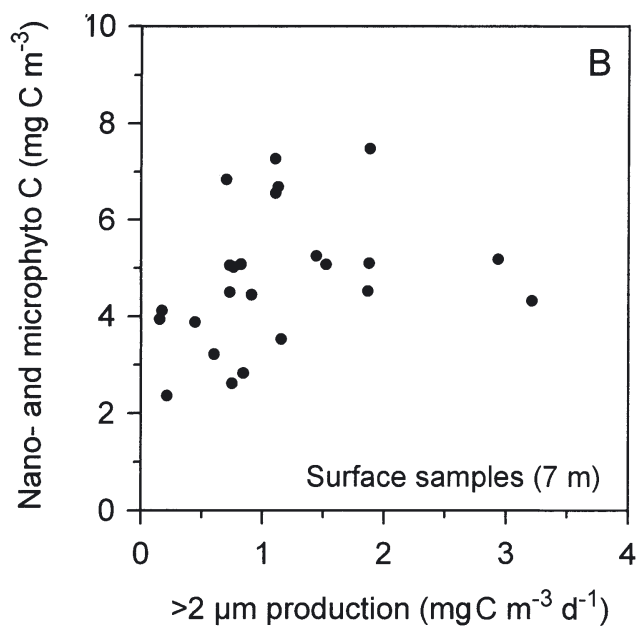

Fig. 6. (A) Relationship between total integrated primary production and integrated chlorophyll a concentration in $>2 \mu \mathrm{m}$ size fraction; (B) relationship between surface primary production in $>2 \mu \mathrm{m}$ size fraction and $\mathrm{C}$ biomass of surface nanoand microphytoplankton

This high variability in our measurements of $\int \mathrm{PP}$ probably reflects the fact that they were obtained in contrasting seasons over a $4 \mathrm{yr}$ period and, more importantly, over very large $(>6000 \mathrm{~km})$ spatial scales. In order to assess the validity of our results, we shall now compare them with satellite-based estimates and in situ measurements of primary production in the Atlantic Subtropical Gyres.

Our average rates of $\int \mathrm{PP}$ at NAST-E and SATL (264 and $171 \mathrm{mgC} \mathrm{m}^{-2} \mathrm{~d}^{-1}$, respectively) are somewhat lower than those calculated by the bio-optical model of Longhurst et al. (1995) (330 and $210 \mathrm{mg} \mathrm{C} \mathrm{m}^{-2} \mathrm{~d}^{-1}$ for NAST-E and SATL, respectively). This is to be expected, given that our sampling (conducted in May and October) did not cover the whole year and, particularly in the NAST-E province, did not include the spring-bloom period, when enhanced production rates occur (Longhurst 1998). We have also compared our productivity measurements in the NAST-E province with those obtained at the BATS (Bermuda Atlantic time-series) station in the Sargasso Sea as reported in Steinberg et al. (2001) and Behrenfeld et al. (2002). The average $\int P P$ at BATS in May and October during the period 1989 to 2001 was $383 \pm$ $134 \mathrm{mg} \mathrm{C} \mathrm{m}^{-2} \mathrm{~d}^{-1}$ compared with our value of $264 \pm 69$ (Table 1). The average value of $P^{B}$ opt at BATS in May and October from 1992 to 1997 was $6.1 \pm 1.8 \mathrm{mgC}$

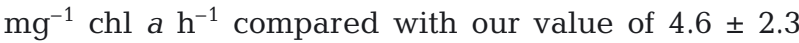
(Table 1). This comparison indicates that the rates of primary production obtained in the subtropical Eastern North Atlantic during this study are similar to, if

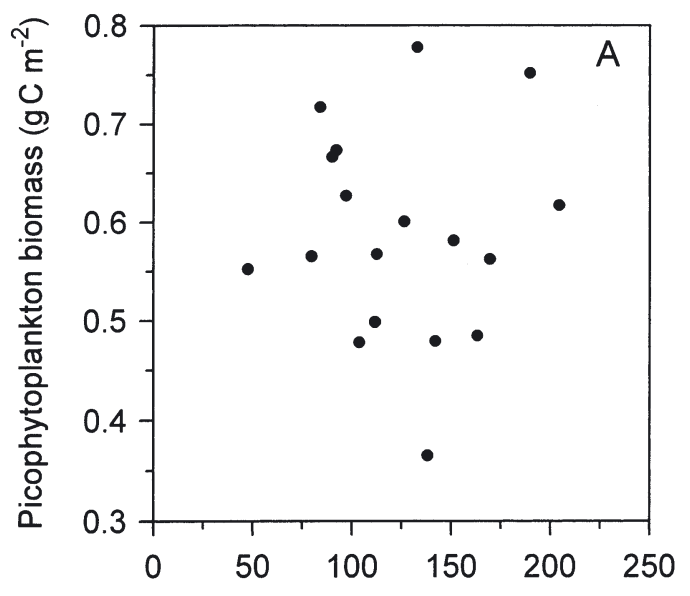

Picophytoplankton production ( $\mathrm{mg} \mathrm{C} \mathrm{m}^{-2} \mathrm{~d}^{-1}$ )

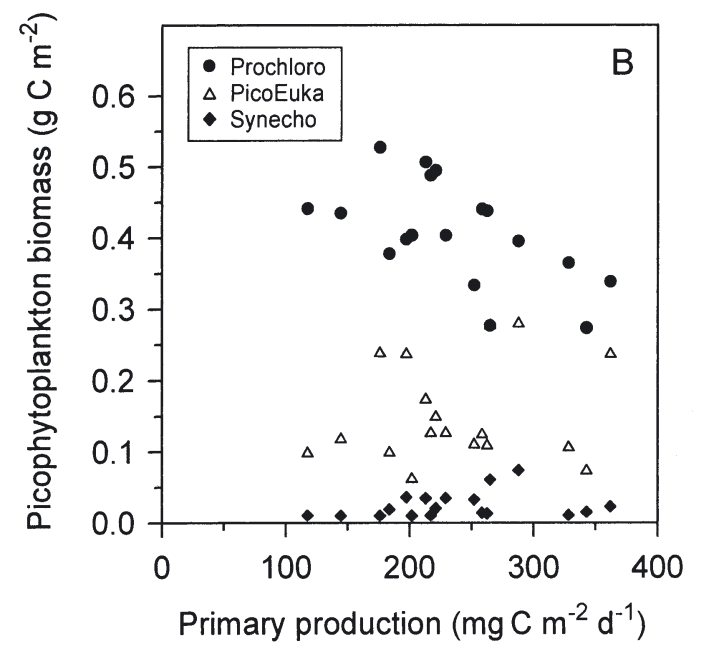

Fig. 7. (A) Relationship between integrated picophytoplankton primary production and integrated picophytoplankton carbon biomass; (B) relationship between total integrated primary production and integrated carbon biomass of Synechococcus spp. (Synecho) and Prochlorococcus spp. (Prochlo), pico-eukaryotic algae (PicoEuka) 
somewhat lower than, those measured in the Sargasso Sea during the BATS programme. One important difference between the BATS site and the NAST-E stations visited during the AMT programme is the location of the nutricline, which at the time of year of our sampling (May and October) is shallower in the former area. Occasionally we measured very low $(<100$ to $150 \mathrm{mg} \mathrm{C} \mathrm{m}^{-2} \mathrm{~d}^{-1}$ ) rates of $\int \mathrm{PP}$, associated with volumetric production to chl ratios of $<1$ to $2 \mathrm{mg} \mathrm{C} \mathrm{mg}^{-1}$ chl $a \mathrm{~h}^{-1}$ in surface waters. These low assimilation numbers have been previously obtained in $P$ - $E$ experiments in the Eastern North Atlantic Gyre (Platt et al. 1983, Frazel \& Berberian 1990) and in the Western South Atlantic Gyre (Hood 1995). In summary, the general agreement between our average productivity rates and those measured by other workers and predicted by bio-optical models, together with the close covariation between the independently determined $P^{B}{ }_{\text {opt }}$ and $P^{B}{ }_{\text {max }}$ (see 'Results'), strongly suggests that the wide dynamic range of $\int \mathrm{PP}$ found in our study truly reflects the variability of phytoplankton dynamics in the oligotrophic waters of the Atlantic Central Gyres.

During our survey of the oligotrophic Atlantic Ocean, phytoplankton chlorophyll showed only minor changes. In addition, we did not find any correlation between picophytoplankton $\mathrm{C}$ biomass and picophytoplankton production, or between primary production in the $>2 \mu \mathrm{m}$ size fraction and the biomass of nano- and microphytoplankton. This relative constancy of phytoplankton biomass in the low-productivity regions of the open ocean reflects the efficient top-down control exerted by microherbivores upon the microalgal assemblages (Banse 1995). A weak or absent relationship between phytoplankton biomass and productivity has been noted in several studies carried out in various oligotrophic regions (Bienfang \& Szyper 1981, Hayward et al. 1983, Malone et al. 1993), in a recent analysis of annual fluxes at time-series stations (Iverson et al. 2000), and again in our results. It thus seems that independent variations in chlorophyll and production are rather the rule than the exception in many vast, low-productivity regions of the open ocean. This uncoupling between chlorophyll and productivity implies that an accurate description of physiological variability (and its impact on the photosynthesis to chlorophyll ratio) is critical in ocean colour-based productivity models applied to oligotrophic regions.

\section{Factors affecting primary productivity}

Our study allowed us to assess the relative importance of different factors in explaining the variability of $\int P P$ in the Subtropical Gyres. Neither chl a concen- tration nor incident irradiance explained any significant fraction of the variability in JPP (Table 2). In contrast, we found significant relationships between $\int \mathrm{PP}$ and temperature and nitracline depth. The lack of relationship between incident irradiance and $\int \mathrm{PP}$ agrees with the results of previous analyses, which demonstrated that irradiance, while critically important in controlling depth-dependent changes in production, explains only a small percentage of the observed station-to-station variability in oceanic productivity (e.g. Behrenfeld \& Falkowski 1997b). The negative relationship between temperature and $\int \mathrm{PP}$ cannot be attributed to temperature-mediated changes in the capacity of the Calvin cycle reactions, since higher temperatures are expected to enhance enzymatic activity. This negative relationship, however, is consistent with the empirical temperature$P^{B}{ }_{\text {opt }}$ relationship described by Behrenfeld \& Falkowski (1997a), which shows a decreasing trend for $P^{B}{ }_{\text {opt }}$ at temperatures above $20^{\circ} \mathrm{C}$. The tendency of $P^{B}{ }^{B}$ opt to decrease with temperature in warm $\left(>20^{\circ} \mathrm{C}\right)$ waters is likely to reflect the frequent association between low nutrient concentrations and high temperatures (e.g. Balch \& Byrne 1994).

The observed relationships between $\int \mathrm{PP}$ and the vertical structure of the water column across a wide geographical range suggest a common mechanism underlying the variability of primary production in the oligotrophic regions of the open ocean. In the expanses of the Subtropical Gyres sampled during this study, warmer surface temperatures are associated with deeper upper mixed layers (see for instance Fig. 9 in Signorini et al. 1999 and Fig. 2 in Marañón et al. 2000). Surface temperature and nitracline depth were significantly correlated $(\mathrm{r}=0.60, \mathrm{p}<0.001, \mathrm{n}=34)$. We also found significant inverse correlations between nitracline depth and both $P^{B}{ }_{\text {opt }}$ and JPP. If the depth of the nitracline can be used as a proxy for nutrient supply to the euphotic layer (e.g. Malone et al.1993), our results suggest that nutrient-dependent changes in photosynthetic performance (as reflected, for instance, in variations of $P^{B}{ }_{\text {opt }}$ and $P^{B}{ }_{\text {max }}$ ) are critical in understanding the variability of $\int \mathrm{PP}$ in the open ocean. This conclusion is reinforced by the good agreement obtained between our measured values of $P^{B}{ }_{\text {opt }}$ and $P^{B}$ max and the results of the PhotoAcc model, which reproduces the variability in Calvin cycle capacity as a function of nutrient status, which in turn is inferred from the relative positions of the nitracline and the pycnocline (Behrenfeld et al. 2002). It thus seems that consideration of nutrientinduced changes in phytoplankton photophysiology represents a promising avenue for future improvements of models aimed at estimating ocean productivity from remotely sensed measurements of ocean colour. 


\section{Phytoplankton size structure, picoplankton composition and productivity}

It has long been recognised that a negative relationship exists between phytoplankton productivity and the relative contribution of small cells (pico- and nano-plankton) to total biomass and productivity (Malone 1980, Kiørboe 1993). This pattern ultimately reflects a linkage between the trophic structure of the planktonic ecosystem and its biogeochemical functioning (Legendre \& Rassoulzadegan 1996). While the negative relationship between total biomass and the fractional contribution of small cells to the standing stocks holds true if data from very diverse environments are pooled (Chisholm 1992), our results indicate that this is not the case when only observations from the oligotrophic ocean are considered. Despite the existence of a 20 -fold range in productivity rates, the size structure of the phytoplankton assemblages did not change significantly, nor did the partitioning of $\mathrm{C}$ fixation between small and large photoautotrophs. If the size distribution of phytoplankton production and biomass can been taken as an indicator of the dominant type of trophic pathway (Legendre \& Rassoulzadegan 1996), then our observations imply that food-web structure and primary productivity are uncoupled in the oligotrophic ocean. As we shall discuss below, this uncoupling, together with the lack of relation between phytoplankton biomass and $\mathrm{C}$ fixation rates, may have implications for our understanding of $\mathrm{C}$ export in the low-productivity regions of the open ocean.

Few studies have addressed concurrently both the biomass and the productivity of picophytoplankton (e.g. Li 1994, Liu et al. 1998). The relationship between picoplankton community composition and productivity observed during this study is consistent with the existing knowledge on the physiology and ecology of Synechococcus spp., Prochlorococcus spp. and the photosynthetic eukaryotes (Chisholm 1992, Partensky et al. 1996). Given that irradiance was not significantly correlated with the changes in $\int P P$, the abundance patterns of each group of picophytoplankton probably reflect differences in the efficiency of nutrient acquisition and use. Prochlorococcus spp. is more efficient at using extremely low nutrient concentrations, whereas Synechococcus spp. and the picoeukaryotes are favoured under less severe oligotrophic conditions (Partensky et al. 1996, Campbell et al. 1998). In fact, we found significant inverse correlations between nitracline depth and the biomass of both Synechococcus spp. $(\mathrm{r}=-0.52, \mathrm{p}<0.05)$ and the picoeukaryotes $(r=-0.58, p<0.05)$. The inverse relationship between total primary production and the contribution of Prochlorococcus spp. to total pico- plankton biomass, which agrees with observations made in the Arabian Sea (Liu et al. 1998) and in the Equatorial Pacific (Liu et al. 1999), has not, to our knowledge, been reported previously for the central gyres of the Atlantic Ocean.

Simultaneous measurements of picoplankton biomass and $\mathrm{C}$ fixation allowed calculations of the integrated growth rates for the picophotoautotrophs, which we found to have an average value of $0.2 \pm$ $0.1 \mathrm{~d}^{-1}$ for the 18 stations where data were available. Using cell-cycle analysis based on flow cytometry, Zubkov et al. (2000) estimated that the growth rate of Prochlorococcus spp. in the Atlantic Ocean is $0.15 \mathrm{~d}^{-1}$. These average growth rates fall within the range of values reported by several authors in other oligotrophic settings of the Atlantic Ocean (e.g. 0.1 to $0.6 \mathrm{~d}^{-1}$ : Malone et al. $1993 ; 0.1$ to $0.3 \mathrm{~d}^{-1}$ : Goericke \& Welschmeyer 1998) where picoplankton accounted for most of the phytoplankton biomass and production. Given that typical growth rates for picoplankton growing under optimal conditions in the laboratory are in the range 0.5 to $1 \mathrm{~d}^{-1}$ (Moore et al. 1995), our results suggest that picoplankton in the oligotrophic Atlantic Ocean are growing at suboptimal growth rates, probably as a result of nutrient limitation (Graziano et al. 1996, Marañón et al. 2000).

\section{Biogeochemical implications}

Most of the organic matter that is produced in the upper oligotrophic ocean is likely to be respired within the euphotic layer, thus not contributing to any export flux. However, recycling efficiency is lower than $100 \%$ and hence some losses, albeit low, do occur. Biogenic $\mathrm{C}$ losses from the euphotic layer take place mainly in 2 ways: sedimentation of particulate organic carbon (POC) and export of dissolved organic carbon (DOC) by vertical diffusion and advection. It seems reasonable to assume that, given that no major changes in food-web structure occur, an increased rate of primary productivity is likely to result in enhanced rates of POC and DOC export. The implication is that the variability in primary productivity is likely to result in variability of $\mathrm{C}$ export, even though microbial biomass and size structure remain unaltered. Across the wide range of primary productivity rates observed in our study, the persistent dominance of picophytoplankton indicates that the microbial loop and the microbial food web continued to be the dominant types of trophic pathway. The resulting view of the oligotrophic ocean is one of a dynamic ecosystem where the microbial community responds to environmental forcing with significant changes in biological rates rather than trophic organization. 
Acknowledgements. E.M. thanks T. Tyrrell and X. A. G. Morán for helpful discussions and comments on an earlier version of the manuscript. A. J. Bale, R. Barciela, D. S. Harbour, A. Pomroy, M. Varela, and M. Woodward contributed to the collection of data. We thank 3 anonymous reviewers for helpful comments and suggestions. This work was funded by research grants from the EU (MAS3CT960060) and the NERC (AMT programme). The contribution of M.J.B. to this work was supported by NASA (RTOP\#622-52-58). This is AMT contribution number 76 .

\section{LITERATURE CITED}

Aiken J, Bale AJ (2000) An introduction to the Atlantic Meridional Transect (AMT) programme. Prog Oceanogr 45: 251-256

Balch WM, Byrne CF (1994) Factors affecting the estimate of primary production from space. J Geophys Res 99:7555-7570

Banse K (1995) Zooplankton: pivotal role in the control of ocean production. ICES J Mar Sci 52:265-277

Behrenfeld MJ, Falkowski PG (1997a) Photosynthetic rates derived from satellite-based chlorophyll concentration. Limnol Oceanogr 42:1-20

Behrenfeld MJ, Falkowski PG (1997b) A consumer's guide to phytoplankton productivity models. Limnol Oceanogr 42 : 1479-1491

Behrenfeld MJ, Marañón E, Siegel DA, Hooker SB (2002) Photoacclimation and nutrient-based model of lightsaturated photosynthesis for quantifying oceanic primary production. Mar Ecol Prog Ser 228:103-117

Bienfang PK, Szyper JP (1981) Phytoplankton dynamics in the subtropical Pacific Ocean off Hawaii. Deep-Sea Res 28: 981-1000

Bowie AR, Whitworth DJ, Achterberg EP, Mantoura RFC, Worsfold PJ (2002) Biogeochemistry of Fe and other trace elements $(\mathrm{Al}, \mathrm{Co}, \mathrm{Ni})$ in the upper Atlantic Ocean. DeepSea Res Part I 49:605-636

Campbell L, Liu H, Nolla HA, Vaulot D (1997) Annual variability of phytoplankton and bacteria in the subtropical North Pacific Ocean at station ALOHA during the 1991-1994 ENSO event. Deep-Sea Res Part I 44:167-192

Campbell L, Landry MR, Constantinou J, Nolla HA, Brown SL, Liu H, Caron DA (1998) Response of microbial community structure to environmental forcing in the Arabian Sea. Deep-Sea Res Part II 45:2301-2325

Chisholm SW (1992) Phytoplankton size. In: Falkowski PG, Woodhead AD (eds) Primary productivity and biogeochemical cycles in the sea. Plenum Press, New York, p 213-237

Fernández E, Marañón E, Morán XAG, Serret P (2003) Potential causes for the unequal contribution of picophytoplankton to total biomass and productivity in oligotrophic waters. Mar Ecol Prog Ser 254:101-109

Frazel DW, Berberian G (1990) Distribution of chlorophyll and primary productivity in relation to water column structure in the eastern North Atlantic Ocean. Global Biogeochem Cycles 4:241-251

Geider RJ (1992) Respiration: taxation without representation? In: Falkowski PG, Woodhead AD (eds) Primary productivity and biogeochemical cycles in the sea. Plenum Press, New York, p 333-360

Gin KYH, Chisholm SW, Olson RJ (1999) Seasonal and depth variation in microbial size spectra at the Bermuda Atlantic time series station. Deep-Sea Res Part I 46:1221-1245

Goericke R, Welschmeyer NA (1998) Response of Sargasso Sea phytoplankton biomass, growth rates and primary production to seasonally varying physical forcing. J Plankton Res 20:2223-2249

Graziano LM, Geider RJ, Li WKW, Olaizola M (1996) Nitrogen limitation of North Atlantic phytoplankton: analysis of physiological condition in nutrient enrichment experiments. Aquat Microb Ecol 11:53-64

Hayward TL, Venrick EL, McGowan JA (1983) Environmental heterogeneity and plankton community structure in the central North Pacific. J Mar Res 41:711-729

Hood RR (1995) Light response of phytoplankton in the South Atlantic Ocean: interpretation of observations and application to remote sensing. J Geophys Res 100:10927-10942

Iverson RL, Esaias WE, Turpie K (2000) Ocean annual phytoplankton carbon and new production, and annual export production estimated with empirical equations and CZCS data. Glob Change Biol 6:57-72

Joint I, Pomroy A, Savidge G, Boyd P (1993) Size fractionated primary production in the North East Atlantic in early summer 1989. Deep-Sea Res 40:423-440

Karl DM, Bidigare RR, Letelier RM (2001) Long-term changes in plankton community structure and productivity in the North Pacific Subtropical Gyre: the domain shift hypothesis. Deep-Sea Res Part II 48:1449-1470

Kiørboe T (1993) Turbulence, phytoplankton cell size and the structure of pelagic food webs. Adv Mar Biol 29:1-72

Kirchman DL (2002) Calculating microbial growth rates from data on production and standing stocks. Mar Ecol Prog Ser 233:303-306

Legendre L, Rassoulzadegan F (1996) Food-web mediated export of biogenic carbon in oceans. Mar Ecol Prog Ser 145:179-193

Li WKW (1994) Primary production of prochlorophytes, cyanobacteria, and eukaryotic ultraphytoplankton: measurements from flow cytometric sorting. Limnol Oceanogr 39:169-175

Liu H, Campbell L, Landry MR, Nolla HA, Brown SL, Constantinou J (1998) Prochlorococcus and Synechococcus growth rates and contributions to production in the Arabian Sea during the 1995 Southwest and Northeast Monsoons. Deep-Sea Res Part II 45:2327-2352

Liu H, Landry MR, Vaulot D, Campbell L (1999) Prochlorococcus growth rates in the central equatorial Pacific: an application of the $f_{\max }$ approach. J Geophys Res 104:3391-3399

Longhurst A (1998) Ecological geography of the sea. Academic Press, San Diego

Longhurst A, Sathyendranath S, Platt T, Caverhill C (1995) An estimate of global primary production in the ocean from satellite radiometer data. J Plankton Res 17:1245-1271

Malone TC (1980) Size-fractionated primary productivity of marine phytoplankton. In: Falkowski PG (ed) Primary productivity in the sea. Plenum Press, New York, p 301-319

Malone TC, Pike SE, Conley DJ (1993) Transient variations in phytoplankton productivity at the JGOFS Bermuda time series station. Deep-Sea Res Part I 40:903-924

Marañón E, Holligan PM (1999) Photosynthetic parameters of phytoplankton from $50^{\circ} \mathrm{N}$ to $50^{\circ} \mathrm{S}$ in the Atlantic Ocean. Mar Ecol Prog Ser 176:191-203

Marañón E, Holligan PM, Varela M, Mouriño B, Bale AJ (2000) Basin-scale variability of phytoplankton biomass, production and growth in the Atlantic Ocean. Deep-Sea Res Part I 47:825-857

Marañón E, Holligan PM, Barciela R, González N, Mouriño B, Pazó MJ, Varela M (2001) Patterns of phytoplankton size structure and productivity in contrasting open ocean environments. Mar Ecol Prog Ser 216:43-56

Moore LR, Goericke R, Chisholm SW (1995) Comparative physiology of Synechococcus and Prochlorococcus: in- 
fluence of light and temperature on growth, pigments, fluorescence and absorptive properties. Mar Ecol Prog Ser 116:259-275

Partensky F, Blanchot J, Lantoine F, Neveux J, Marie D (1996) Vertical structure of picophytoplankton at different trophic sites of the tropical northeastern Atlantic Ocean. Deep-Sea Res Part I 43:1191-1213

Platt T, Subba Rao DV, Irwin B (1983) Photosynthesis of picoplankton in the oligotrophic ocean. Nature 301:702-704

Signorini SR, Murtugudde RG, McClain CR, Christian JR, Picaut J, Busalacchi AJ (1999) Biological and physical signatures in the tropical and subtropical Atlantic. J Geophys Res 104:18367-18382

Editorial responsibility: Otto Kinne (Editor), Oldendorf/Luhe, Germany
Steinberg DK, Carlsson CA, Bates NR, Johnson RJ, Michaels AF, Knap AH (2001) Overview of the US JGOFS Bermuda Atlantic time-series study (BATS): a decade-scale look at ocean biology and biogeochemistry. Deep-Sea Res Part II 48:1405-1447

Zubkov MV, Sleigh MA, Tarran GA, Burkill PH, Leakey RJG (1998) Picoplanktonic community structure on an Atlantic transect from $50^{\circ} \mathrm{N}$ to $50^{\circ} \mathrm{S}$. Deep-Sea Res Part I 45: $1339-1355$

Zubkov MV, Sleigh MA, Burkill PH (2000) Assaying picoplankton distribution by flow cytometry of underway samples collected along a meridional transect across the Atlantic Ocean. Aquat Microb Ecol 21:13-20

Submitted: January 29, 2003; Accepted: April 29, 2003 Proofs received from author(s): July 28, 2003 